\title{
ОЦІНКА ПЕРСПЕКТИВНОСТІ ЗАСТОСУВАННЯ ОСТЕОІНДУКТИВНИХ МАТЕРІАЛІВ ЗА ДАНИМИ ДЕНСИТОМЕТРІї ДЛЯ РЕКОНСТРУКЦІї ДЕФЕКТІВ КІСТКОВОї ТКАНИНИ У ДИНАМІЦІ ЕКСПЕРИМЕНТУ В ПІСЛЯОПЕРАЦІЙНИЙ ПЕРІОД
}

\section{Тернопільський національний медичний університет імені І. Я. Горбачевського МОЗ України}

РЕЗЮМЕ. Кісткова тканина для більшості спеціалістів, які працюють у галузі медицини, $є$ невідомою частиною в організмі людини. Порушення мінеральної щільності кісткової тканини (МЩКТ), за даними Всесвітньої організації охорони здоров' я, за поширеністю посідає четверте місце у світі - після серцево-судинних, онкологічних захворювань і цукрового діабету.

На сьогодні використання збагаченої тромбоцитами плазми (ЗТП) є одним із успішних напрямків тканинної інженерії та клітинної терапії в медицині. Використання факторів росту особливо цікаве в тих випадках, коли ефективність кісткових матеріалів і остеоінтеграції досить сумнівні (наприклад, при вираженому остеопорозі або рубцевих змінах тканин).

Мета - оцінити перспективність застосування остеоіндуктивих матеріалів для реконструкції дефектів кісткової тканини.

Матеріал і методи. Остеопластичні властивості матеріалів досліджували на моделі кісткового дефекту стегнової кістки діафізарної зони у чотиримісячних щурів породи Вістар. Було сформовано 4 експерементальні групи: контрольна група (інтактні тварини) - 12 особин; I група - 14 тварин, для загоєння кісткового дефекту застосовували остеопластичний матеріал «mp3 OsteoBiol»; II група - 13 тварин, заповнення кісткового дефекту збагаченою тромбоцитами плазмою (ЗТП); III група - 15 тварин, при аугментації кісткового дефекту застосовували композицію «mp3 OsteoBiol + ЗТП». Для отримання збагаченої тромбоцитами плазми крові у хворого за допомогою венопункції забирали 30 мл крові, котру центрифугували з подвійним циклом обертів, після чого у пробірці кров поділялась на 3 частини. Шприцом відбирали середню - тягучу масу жовтуватого кольору (ЗТП). При проведенні досліджень здійснювали локальну денситометрію з метою вимірювання оптичної щільності кісткової тканини. Статистичну обробку отриманих результатів проведено на персональному комп'ютері за допомогою ліцензійних програм «Microsoft Excel» i «Statistica».

Результати. Через 3 місяці було встановлено, що максимальне значення МЩКТ у інтактних тварин статистично не відрізнялось від аналогічного параметра у щурів III групи $((1199,25 \pm 63,70)$ HU i $(1145,0 \pm 62,71)$ HU, відповідно, p, $\left.\mathrm{p}_{1}>0,05, \mathrm{p}_{2}<0,01\right)$. При цьому у тварин I і II експериментальних груп максимальні значення МщКТ були у 1,2 раза $(p<0,05)$ та у 1,4 раза $\left(p_{1}<0,05\right)$ відповідно нижчі, ніж у тварин контрольної групи. Мінімальні дані МщКТ у щурів контрольної та III експериментальної груп дорівнювали між собою $((924,19 \pm 67,00) \mathrm{HU}$ і $(849,26 \pm 59,22) \mathrm{HU}, \mathrm{p>0}, 05$, $\mathrm{p}_{1}, \mathrm{p}_{2}<0,05$ відповідно). При цьому дані цього параметра у щурів I та II піддослідних груп залишались у 1,5 раза меншими, ніж у тварин контрольної групи, p<0,01, p >0,05. Водночас аналіз середніх даних МщКТ показав, що значення цього параметра дорівнювали між собою у тварин контрольної та III піддослідної груп, p>0,05, $p_{1}, p_{2}<0,05$. Водночас середнє значення МЩКТ у тварин I та II експериментальних груп було у 1,2 раза та у 1,3 раза $\left(p_{1}>0,05\right)$ нижчим, ніж у тварин контрольної групи $(p<0,05)$.

Висновки. За даними клінічних ознак післяопераційного періоду та денситометричних досліджень встановлено, що запропонована нами композиція, що містила «mp3 OsteoBiol» та збагачену тромбоцитами плазму крові, сприяла пришвидшенню процесу регенерації кісткової тканини, порівняно з групами, у яких застосовували вищезгадані препарати поодинці, без запального процесу, з формуванням новоутвореної кістки, яка мала зрілий характер.

КлючОВІ СлОВА: остеопластичний матеріал; денситометрія; післяопераційний період; збагачена тромбоцитами плазма; фактори росту; регенерація кісткової тканини.

Вступ. Кісткова тканина для більшості спеціалістів, що працюють у галузі медицини, $є$ невідомою частиною в організмі людини. Порушення мінеральної щільності кісткової тканини (МЩКТ), за даними Всесвітньої організації охорони здоров'я, за поширеністю посідає четверте місце у світі - після серцево-судинних, онкологічних захворювань i цукрового діабету [1-3]. Прагнення науковців об'єктивно оцінити структурно-функціональний стан кісткової тканини в хворих та розробити адекватні методи його корекції медикаментозним та хірургічним шляхами привело до застосування різ- номанітних методик обстеження: кількісної ультразвукової денситометрії та комп'ютерної томографії [4], фотонної абсорбціометрії, рентгенівської денситометрії тощо [5-8].

У численних дослідженнях показаний лікувальний ефект аутологічно збагаченої тромбоцитами плазми при загоєнні кісткової і м'якої тканин після відновної та реконструктивної хірургії в стоматології $[9,10]$.

3 початку 1990-х років досліджували специфічний продукт - збагачену тромбоцитами плазму (ЗТП) і вплив факторів росту, що містяться в 
Огляди літератури, оригінальні дослідження, погляд на проблему, випадок з практики, короткі повідомлення ній, на кістковий матеріал при проведенні реконструктивних втручань на щелепах [11]. Фактори росту і диференціації є класом біологічних медіаторів, котрі відіграють важливу роль у стимуляції і регулюють загоєння ран, а також ключові клітинні процеси, включаючи мітогенез, хемотаксис, диференціацію і метаболізм [12]. Перевагами використання аутологічної ЗТП є безпечність (відсутність ризику інфекційних захворювань або виникнення імуногенних реакцій) та неінвазивність самої процедури, доставка факторів росту і цитокінів безпосередньо в ділянку рани, швидкість і простота приготування препарату [13].

Використання факторів росту особливо привабливе в тих випадках, коли ефективність кісткових матеріалів і остеоінтеграції досить сумнівні (наприклад, при вираженому остеопорозі або рубцевих змінах тканин) $[14,15]$. Такі дослідження могли 6 розкрити додаткові переваги використання вказаного методу лікування для загоєння ран і регенерації кістки.

Мета - оцінити перспективність застосування остеоіндуктивих матеріалів для реконструкції дефектів кісткової тканини.

Матеріал і методи дослідження. Остеопластичні властивості матеріалів досліджували на моделі кісткового дефекту стегнової кістки діафізарної зони у чотиримісячних щурів породи Вiстар. Під нембуталовим наркозом, після обробки операційного поля 70 \% спиртовим розчином хлоргексидину по передньомедіальній поверхні стегна проводили розріз шкіри завдовжки 5 см. М'язи тупим способом розводили і фіксували [16]. За допомогою остеотома на передній поверхні стегна щура моделювали кістковий дефект розміром 0,5 см, котрий заповнювали остеоіндуктивним матеріалом. Згодом було сформовано експериментальні групи:

- І група - 14 тварин, для загоєння кісткового дефекту в яких застосовували остеопластичний матеріал «mp3 OsteoBiol»;

- II група - 13 тварин, у яких кістковий дефект заповнювали збагаченою тромбоцитами плазмою (ЗТП);

- III група - 15 тварин, в яких при аугментації кісткового дефекту застосовували композицію «mp3 OsteoBiol + 3ТП»;

• контрольна група (інтактні тварини) - 12 особин.

Отримані дані на 90 добу спостережень порівнювали зі значеннями у 12 інтактних щурів.

Для отримання збагаченої тромбоцитами плазми крові (ЗТП) у хворого за допомогою венопункції забирали 30 мл крові [17]. У якості антикоагулянта використовували цитратний антикоагулянт з декстрозою, одноразовий контейнер, заповнений кров'ю хворого, центрифугували 3 подвійним циклом обертів. У пробірці кров поділялась на 3 частини. Шприцом відбирали середню - тягучу масу жовтуватого кольору (збагачену тромбоцитами плазму) [18]. При проведенні досліджень здійснювали локальну денситометрію 3 метою вимірювання оптичної щільності кісткової тканини. Показник денситометрії досліджуваного вогнища деструкції кісткової тканини визначали з використанням комп'ютерної програми (автоматично у відносних величинах (\%)) $[14,16]$. Статистичну обробку отриманих результатів проведено на персональному комп' ютері за допомогою ліцензійних програм «Microsoft Excel» i «Statistica».

Результати й обговорення. В результаті порівняльного аналізу клінічної картини в експериментальних тварин (табл. 1) встановлено, що у ранньому післяопераційному періоді (1-3 доба) тварини були мляві, мало рухались, не спирались на прооперовану кінцівку. Відновлення здатності опиратися на прооперовану кінцівку у щурів I-ІІ піддослідних груп спостерігали через $(5,30 \pm 0,91)$ діб та $(6,20 \pm 0,20)$ діб відповідно, р>0,05. У піддослідних тварин III групи ця функція відновлювалась на $(5,0 \pm 0,20)$ добу, що не відрізнялось від даних у І групі, p>0,05, але було у 1,2 раза менше, ніж у щурів II дослідної групи, $\mathrm{p}_{1}<0,01$.

Загоєння операційної шкірної рани досліджували на $(6,80 \pm 0,90)$ добу в тварин III групи та на $(7,50 \pm 0,80)$ добу в щурів I групи, p>0,05. У прооперованих тварин II групи загоєння шкірної рани

Таблиця 1. Перебіг післяопераційного періоду в експериментальних тварин

\begin{tabular}{|l|c|c|c|}
\hline \multirow{2}{*}{\multicolumn{1}{|c|}{ Досліджувані ознаки }} & \multicolumn{2}{|c|}{ Доба після операції } \\
\cline { 2 - 4 } & $\begin{array}{c}\text { I група («mp3 OsteoBiol») } \\
(\mathrm{n=14)}\end{array}$ & $\begin{array}{c}\text { II група (3ТП) } \\
\text { (n=13) }\end{array}$ & $\begin{array}{c}\text { III група («mp3 } \\
\text { OsteoBiol» + 3TП) (n=15) }\end{array}$ \\
\hline $\begin{array}{l}\text { Відновлення здатності опиратися } \\
\text { на прооперовані кінцівки }\end{array}$ & $5,30 \pm 0,91$ & $6,20 \pm 0,20$ & $5,0 \pm 0,20 *$ \\
\hline Загоєння операційної шкірної рани & $7,50 \pm 0,80$ & $8,95 \pm 0,90^{\circ}$ & $6,80 \pm 0,70$ \\
\hline Купірування набряку & $8,72 \pm 0,90$ & $11,70 \pm 0,80^{\circ}$ & $7,60 \pm 0,80^{*}$ \\
\hline
\end{tabular}

Примітки:

1. ${ }^{\circ}<<0,05$ - достовірна різниця значень стосовно даних I групи;

2. * $\mathrm{p}_{1}<0,01$ - достовірна різниця значень стосовно даних II групи. 
Огляди літератури, оригінальні дослідження, погляд на проблему, випадок з практики, короткі повідомлення проходило дещо довше та по термінах було у 1,2 раза та у 1,3 раза більшим, ніж у піддослідних тварин I та III експериментальних груп відповідно, $p_{1}>0,05, p_{2}<0,05$.

При цьому купірування набряку відбувалось на $(7,60 \pm 0,80)$ добу в тварин III групи, що тривало у 1,5 раза менше, ніж у піддослідних тварин II групи, $\mathrm{p}_{1}<0,01$, та не відрізнялось статистичною значущістю від даних у I групі, p>0,05. Привертало увагу, що зникнення набряку у щурів I групи відбувалось у

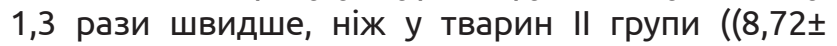
0,90) діб проти $(11,70 \pm 0,80)$ діб відповідно, $p<0,05)$.

Для визначення мінеральної щільності кісткової тканини у ділянці дефекту кістки при використанні остеотропних препаратів та їх компози-

цій було проведено денситометричне дослідження через 30, 60, 90 діб експерименту.

Через 30 діб дослідження ми встановили (табл. 2), що мінімальні значення МЩКТ визначалися у тварин II групи - $(80,0 \pm 10,00) \mathrm{HU}, \mathrm{p}_{1}<0,01$, при оптимальних даних цього показника у щурів III групи - $(179,95 \pm 18,75) \mathrm{HU}, \mathrm{p}_{1}>0,05, \mathrm{p}_{2}<0,01$. Водночас максимальні значення МЩКТ визначалися

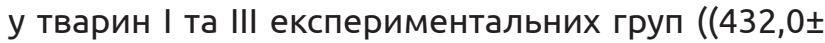
$54,12) \mathrm{HU}$ та $(487,50 \pm 56,0) \mathrm{HU}, \mathrm{p}_{1}>0,05, \mathrm{p}_{2}<0,01$ відповідно). Привертало увагу, що на 30 добу спостережень середнє значення МЩКТ у тварин I та III груп не відрізнялось статистичною значущістю між собою, $\mathrm{p}_{1}>0,05$, але було в середньому в 2,0 рази вище, ніж у тварин II групи, $\mathrm{p}_{1}, \mathrm{p}_{2}<0,01$.

Таблиця 2. Динаміка денситометричних показників у експериментальних тварин при відновленні кісткових дефектів остеопластичними матеріалами у різні терміни спостереження

\begin{tabular}{|c|c|c|c|c|}
\hline Показники & $\begin{array}{c}\text { Контрольна група } \\
\text { (інтактні тварини) } \\
(n=12)\end{array}$ & $\begin{array}{c}\text { I група } \\
\text { («mp3 OsteoBiol») } \\
(n=14)\end{array}$ & $\begin{array}{l}\text { II група } \\
\text { (3ТП) } \\
(n=13)\end{array}$ & $\begin{array}{c}\text { III група } \\
(\text { «mp3 OsteoBiol» }+3 T \Pi) \\
(n=15)\end{array}$ \\
\hline \multicolumn{5}{|c|}{ На 30 добу дослідження } \\
\hline Максимальне & - & $432,0 \pm 54,12$ & $228,60 \pm 21,40 *$ & $\begin{array}{c}487,50 \pm 56,0 \\
\Delta\end{array}$ \\
\hline Мінімальне & - & $168,40 \pm 18,20$ & $\begin{array}{c}80,0 \pm 10,00 \\
*\end{array}$ & $179,95 \pm 18,75 \Delta$ \\
\hline Середнє & - & $286,0 \pm 24,15$ & $154,30 \pm 17,00 *$ & $330,80 \pm 42,78 \Delta$ \\
\hline \multicolumn{5}{|c|}{ На 60 добу дослідження } \\
\hline Максимальне & - & $602,70 \pm 59,60$ & $593,30 \pm 52,0$ & $\begin{array}{c}858,20 \pm 62,0 \\
* *, \Delta\end{array}$ \\
\hline Мінімальне & - & $339,10 \pm 42,00$ & $250,0 \pm 22,17$ & $450,65 \pm 51,26 \Delta$ \\
\hline Середнє & - & $450,10 \pm 50,0$ & $320,85 \pm 41,20$ & $683,63 \pm 61,20 * *, \Delta$ \\
\hline \multicolumn{5}{|c|}{ На 90 добу дослідження } \\
\hline Максимальне & $1199,25 \pm 63,70$ & $\underset{\substack{9 \\
\text { o }}}{987,50 \pm 59,40}$ & 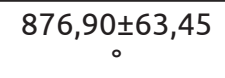 & $1145,0 \pm 62,71 \Delta$ \\
\hline Мінімальне & $924,19 \pm 67,00$ & $\begin{array}{c}624,18 \pm 60,44 \\
\circ\end{array}$ & $\underset{\substack{621,72 \pm 61,00 \\
\circ}}{ }$ & $849,26 \pm 59,22 * *, \Delta \Delta$ \\
\hline Середнє & $1005,72 \pm 69,15$ & $805, \underset{\text { оo }}{80 \pm 63,17}$ & $749,30 \pm 62,42$ & $997,13 \pm 66,37 * *, \Delta \Delta$ \\
\hline
\end{tabular}

Примітки:

1. ${ }^{\circ} \mathrm{p}<0,01 ;{ }^{\circ} \mathrm{p}<0,05$ - достовірна різниця значень стосовно даних у інтактних тварин;

2. ${ }^{*} \mathrm{p}_{1}<0,01 ;{ }^{* *} \mathrm{p}_{1}<0,05$ - достовірна різниця значень стосовно даних у I групі;

3. $\Delta \mathrm{p}_{2}<0,01 ; \Delta \Delta \mathrm{p}_{2}<0,05$ - достовірна різниця значень стосовно даних II групи.

Через 60 діб спостережень параметри МЩКТ покращувались в усіх експериментальних групах, однак у I та II групах максимальні та мінімальні дані МЩКТ не відрізнялись статистичною значущістю між собою $\mathrm{p}_{1}>0,05$, але були вірогідно нижчими, ніж у тварин III групи, $\mathrm{p}_{1}<0,05, \mathrm{p}_{2}<0,01$. Аналіз середніх даних МЩКТ у вказаний термін спостережень показав, що оптимальні значення цього параметра визначались у щурів III групи - $(683,63 \pm 61,20) \mathrm{HU}$, $\mathrm{p}_{1}<0,05, \mathrm{p}_{2}<0,01$, і були вищими у 1,5 раза та у 2,1 раза, ніж у тварин I та II груп відповідно.
Через 3 місяці досліджень було встановлено, що максимальне значення МЩКТ у інтактних тварин статистично не відрізнялось від аналогічного параметра у щурів III групи $((1199,25 \pm 63,70) \mathrm{HU}$ i $(1145,0 \pm 62,71) \mathrm{HU}$, відповідно, $\left.p_{1} \mathrm{p}_{1}>0,05, \mathrm{p}_{2}<0,01\right)$. При цьому у тварин I і II експериментальних груп максимальні значення МЩКТ були у 1,2 раза, $\mathrm{p}<0,05$ та у 1,4 раза, $\mathrm{p}_{1}<0,05$, відповідно, нижчими, ніж у тварин контрольної групи. Мінімальні дані МЩКТ у щурів контрольної та III експериментальної груп дорівнювали між собою $(924,19 \pm 67,00 \mathrm{HU}$ 
Огляди літератури, оригінальні дослідження, погляд на проблему, випадок з практики, короткі повідомлення і 849,26士59,22 HU, p>0,05, $\mathrm{p}_{1}, \mathrm{p}_{2}<0,05$, відповідно). При цьому дані цього параметра у щурів I та II піддослідних груп залишались у 1,5 раза меншими, ніж у тварин контрольної групи, $р<0,01, \mathrm{p}_{1}>0,05$. Водночас, аналіз середніх даних МЩКТ показав, що значення цього параметра дорівнювали між собою у тварин контрольної та III піддослідної груп, p>0,05, $p_{1}, p_{2}<0,05$. У той же час середнє значення МЩКТ у тварин I та II експериментальних груп було у 1,2 раза та у 1,3 раза, $\mathrm{p}_{1}>0,05$, меншим, ніж у тварин контрольної групи, $p<0,05$.

Висновок. За даними клінічних ознак післяопераційного періодута результатами денситометричних досліджень встановлено, що запропонова-

на нами композиція, що містила «mp3 OsteoBiol» та збагачену тромбоцитами плазму крові, сприяла пришвидшенню процесу регенерації кісткової тканини, порівняно з групами, в яких застосовували вищезгадані препарати поодинці, без запального процесу, з формуванням новоутвореної кістки, яка мала зрілий характер.

Перспективи подальших досліджень. Планується вивчення впливу остеотропних препаратів у поєднанні зі збагаченою тромбоцитами плазмою на організм людини з можливістю подальшого застосуванням при закриті кісткових дефектів у стоматології.

\section{ЛІТЕРАТУРА}

1. Fungus ball of the maxillary sinus-modern treatment by osteoplastic approach and functional endoscopic sinus surgery / A. Naros, J. P. Peters, T. Biegner [et al.] // Journal of oral and maxillofacial surgery: official journal of the American Association of Oral and Maxillofacial Surgeons. - 2019. - Vol. 77 (3). - P. 546-554. - Access mode : https://doi.org/10.1016/j.joms.2018.10.010.

2. Late mandibular fracture occurring in the postoperative period after third molar removal: systematic review and analysis of 124 cases / W. R. Pires, J. P. Bonardi, L. P. Faverani [et al.] // International Journal of Oral and Maxillofacial Surgery. - 2017. - Vol. 46 (1). - P. 46-53. - Access mode : https://doi.org/10.1016/j.ijom.2016.09.003.

3. Жулкевич І. В. Вікова динаміка змін стану мінеральної щільності кісткової тканини у хворих на хронічну лімфоїдну лейкемію / І.В.Жулкевич, Р. Й. Вибирана, К. В. Баранніков // Вісник наукових досліджень. 2013. - № 1. - C. 47-50. https://doi.org/10.11603/24158798.2013.1.5700

4. Жулкевич І. В. Клініко-діагностична апробація методу віртуальної біопсії кісткової тканини у хворих на лімфому Годжкіна / І. В. Жулкевич, Ю. В. Яворська // Український радіологічний журнал. - 2015. - Т. XXIII. C. 31-34.

5. Effect of oral administration of bromelain on postoperative discomfort after third molar surgery / P. Ghensi, A. Cucchi, L. Creminelli [et al.] // Journal of Craniofacial Surgery. - 2017. - Vol. 28 (2). - P. e191-e197. - Access mode : https://doi.org/10.1097/SCS.0000000000003154.

6. Жулкевич І. В. Дослідження структурно-функціонального стану кісткової тканини методом двофотонної рентгенівської абсорбціометрії / І.В.Жулкевич, О. Л. Ковальчук // Шпитальна хірургія. - 1999. - № 2. C. 124-129.

7. The interrelationship of bone and cardiovascular remodeling biomarkers and clinical peculiarities of coronary artery disease in postmenopausal women / N. S. Mykhailovska, I. O. Stetsiuk, T. O. Kulynych [et al.] // Rheumatology. - 2020. - Vol. 58 (3). - P. 142-149. - Access mode : https://doi.org/10.5114/reum.2020.96687.

8. Correspondence between dental and skeletal maturity parameters among patients with different sagittal relationships at the end of puberty period / M. GoncharukKhomyn, E. Akleyin, I. Zhulkevych [et al.] // J. Int. Dent. Med. Res. - 2020. - Vol. 13 (1). - P. 223-228.

9. Postoperative pain intensity after using different instrumentation techniques: a randomized clinical study / E. Çiçek, M. M. Koçak, S. Koçak [et al.] // Journal of Applied Oral Science. - 2017. - Vol. 25 (1). - P. 20-26. - Access mode : https://doi.org/10.1590/1678-77572016-0138.

10. Mobini A. Postoperative pain and opioid analgesic requirements after orthognathic surgery / A. Mobini, P. Mehra, R. Chigurupati // J. Oral Maxillofac. Surg. 2018. - Vol. 76 (11). - P. 2285-2295. - Access mode : https://doi.org/10.1016/j.joms.2018.05.014.

11. McCullough J. J. The effect of implant macrothread design on implant stability in the early post-operative period: a randomized, controlled pilot study / J. J. McCullough, P. R. Klokkevold // Clinical Oral Implants Research. - 2017. - Vol. 28 (10). - P. 1218-1226. - Access mode : https://doi.org/10.1111/clr.12945.

12. Comparative release of growth factors from PRP, PRF, and advanced-PRF / E. Kobayashi, L. Flückiger, M. Fujioka-Kobayashi [et al.] // Clinical Oral Investigations. 2016. - Vol. 20 (9). - P. 2353-2360. - Access mode : https:// doi.org/10.1007/s00784-016-1719-1.

13. Impact of incubation method on the release of growth factors in non-Ca2+-activated PRP, Ca2+-activated PRP, PRF and A-PRF / D. Steller, N. Herbst, R. Pries [et al.] // J. Craniomaxillofac Surg. - 2019. - Vol. 47 (2). - P. 365372. - Access mode : https://doi.org/10.1016/j. jcms.2018.10.017.

14. Platelet rich plasma (PRP) produces an atherofibrotic histophenotype during craniofacial bone repair due to changes of immunohistochemical expression of Erk1/2, $\mathrm{p} 38 \mathrm{a} / \boldsymbol{\beta}$, Adiponectin and elevated presence of cells exhibiting B-scavenger receptor (CD36+) / C. C. Schroeder, J. S. Scariot, J. C. Ribeiro [et al.] // Braz. Dent. J. 2016. - Vol. 27 (3). - P. 243-254. - Access mode : https://doi. org/10.1590/0103-6440201602450. 
Огляди літератури, оригінальні дослідження, поглядн на

15. Масик О. М. Сучасні аспекти застосування біфосфонатів у клінічній практиці (огляд літератури) / О. М. Масик, С. І. Сміян, І. В. Жулкевич // Журнал АМН України. - 2000. - Т. 6, № 4. - С. 713-721.

16. Effect of liquid platelet-rich fibrin and plateletrich plasma on the regenerative potential of dental pulp cells cultured under inflammatory conditions: A comparative analysis / J. Chai, R. Jin, G. Yuan [et al.] // J. Endod. 2019. - Vol. 45 (8). - P. 1000-1008. - Access mode : https:// doi.org/10.1016/j.joen.2019.04.002.

17. Platelet-rich plasma: A study of the variables that may influence its effect on bone regeneration / M. D. Jo-
vani-Sancho, C. C. Sheth, M. Marqués-Mateo, M. PucheTorres // Clinical Implant Dentistry and Related Research. 2016. - Vol. 18 (5). - P. 1051-1064. - Access mode : https:// doi.org/10.1111/cid.12361.

18. Platelet-rich plasma for regeneration of neural feedback pathways around dental implants: a concise review and outlook on future possibilities / Y. Huang, M. M. Bornstein, I. Lambrichts [et al.] // International Journal of Oral Science. - 2017. - Vol. 9 (1). - P. 1-9. - Access mode : https://doi.org/10.1038/ijos.2017.1.

\section{REFERENCES}

1. Naros, A., Peters, J.P., Biegner, T., Weise, H., Krimmel, M., \& Reinert, S. (2019). Fungus ball of the maxillary sinus-modern treatment by osteoplastic approach and functional endoscopic sinus surgery. Journal of oral and maxillofacial surgery: official journal of the American Association of Oral and Maxillofacial Surgeons, 77 (3), 546-554. Retrieved from: https://doi.org/10.1016/j.joms.2018.10.010.

2. Pires, W.R., Bonardi, J.P., Faverani, L.P., Momesso, G.A., Muñoz, X.M., Silva, A. F., ..., \& Ponzoni, D. (2017). Late mandibular fracture occurring in the postoperative period after third molar removal: systematic review and analysis of 124 cases. International Journal of Oral and Maxillofacial Surgery, 46 (1), 46-53. Retrieved from: https:// doi.org/10.1016/j.ijom.2016.09.003.

3. Zhulkevych, I.V., Vybyrana, R.Y., \& Barannikov, K.V. (2013). Vikova dynamika zmin stanu mineralnoi shchilnosti kistkovoi tkanyny u khvorykh na khronichnu limfoidnu leikemiiu [Age dynamics of bone mineral density in patients with chronic lymphoid leukemia]. Visnyk naukovykh doslidzhen - Bulletin of Scientific Research, 1, 47-50. Retrieved from: https://doi.org/10.11603/2415-8798.2013.1.5700 [in Ukrainian].

4. Zhulkevych, I.V., \& Yavorska, Yu.V. (2015). Klinikodiahnostychna aprobatsiia metodu virtualnoi biopsii kistkovoi tkanyny u khvorykh na limfomu Hodzhkina [Clinical and diagnostic testing of the method of virtual bone biopsy in patients with Hodgkins lymphoma]. Ukrainskyi radiolohichnyi zhurnal - Ukrainian Journal of Radiology, XKHIII, 31-34 [in Ukrainian].

5. Ghensi, P., Cucchi, A., Creminelli, L., Tomasi, C., Zavan, B., \& Maiorana, C. (2017). Effect of oral administration of Bromelain on postoperative discomfort after third molar surgery. Journal of Craniofacial Surgery, 28 (2), e191-e197. Retrieved from: https://doi.org/10.1097/ SCS.0000000000003154.

6. Zhulkevych, I.V., \& Kovalchuk, O.L. (1999). Doslidzhennia strukturno-funktsionalnoho stanu kistkovoi tkanyny metodom dvofotonnoi renthenivskoi absorbtsiometrii [Investigation of the structural and functional state of bone tissue by the method of two-photon X-ray absorptiometry]. Shpytalna khirurhiia - Hospital Surgery, 2, 124-129 [in Ukrainian].

7. Mykhailovska, N.S., Stetsiuk, I.O., Kulynych, T.O., Gorbachova, S.V., \& Zhulkevych, I.V. (2020). The interrelationship of bone and cardiovascular remodeling biomar- kers and clinical peculiarities of coronary artery disease in postmenopausal women. Rheumatology, 58 (3), 142-149.

8. Goncharuk-Khomyn, M., Akleyin, E., Zhulkevych, I., Nahirnyi, Ya., Brekhlichuk, P., Mochalov, Y., ..., \& Stoika, O. (2020). Correspondence between dental and skeletal maturity parameters among patients with different sagittal relationships at the end of puberty period. J. Int. Dent. Med. Res., 13 (1), 223-228.

9. Çiçek, E., Koçak, M.M., Koçak, S., Sağlam, B.C., \& Türker, S.A. (2017). Postoperative pain intensity after using different instrumentation techniques: a randomized clinical study. Journal of Applied Oral Science, 25 (1), 20-26. Retrieved from: https://doi.org/10.1590/1678-77572016-0138.

10. Mobini, A., Mehra, P., \& Chigurupati, R. (2018). Postoperative pain and opioid analgesic requirements after orthognathic surgery. J. Oral Maxillofac. Surg., 76 (11), 2285-2295. Retrieved from: https://doi.org/10.1016/j. joms.2018.05.014.

11. McCullough, J.J., \& Klokkevold, P.R. (2017). The effect of implant macro-thread design on implant stability in the early post-operative period: a randomized, controlled pilot study. Clinical Oral Implants Research, 28 (10), 12181226. Retrieved from: https://doi.org/10.1111/clr.12945.

12. Kobayashi, E., Flückiger, L., Fujioka-Kobayashi, M., Sawada, K., Sculean, A., Schaller, B., \& Miron, R.J. (2016). Comparative release of growth factors from PRP, PRF, and advanced-PRF. Clinical Oral Investigations, 20 (9), 2353-2360. Retrieved from: https:/doi.org/10.1007/s00784-016-1719-1.

13. Steller, D., Herbst, N., Pries, R., Juhl, D., \& Hakim, S.G. (2019). Impact of incubation method on the release of growth factors in non-Ca ${ }^{2+}$-activated $\mathrm{PRP}, \mathrm{Ca}^{2+}$-activated PRP, PRF and A-PRF. J. Craniomaxillofac. Surg., 47 (2), 365-372. Retrieved from:https://doi.org/10.1016/j.jcms.2018.10.017.

14. Schroeder, C.C., Scariot, J.S., Ribeiro, J.C., Deliberador, T.M., \& Giovanini, A.M. (2016). Platelet rich plasma (PRP) produces an atherofibrotic histophenotype during craniofacial bone repair due to changes of immunohistochemical expression of Erk1/2, p38a/ $\beta$, Adiponectin and elevated presence of cells exhibiting B-scavenger receptor (CD36+). Braz. Dent. J., 27 (3), 243-254. Retrieved from: https://doi.org/10.1590/0103-6440201602450.

15. Masyk, O.M., Smiyan, S.I., Zhulkevych, I.V. (2000). Suchasni aspekty zastosuvannia bifosfonativ u klinichnyi praktytsi (ohliad literatury) [Modern aspects of the use of 
Огляди літератури, оригінальні дослідження, погляд на проблему, випадок з практики, короткі повідомлення bisphosphonates in clinical practice (literature review)]. Zhurnal AMN Ukrainy - J. Academy Med. Sci. Ukraine, 6 (4), 713-721 [in Ukrainian].

16. Chai, J., Jin, R., Yuan, G., Kanter, V., Miron, R.J., \& Zhang, Y. (2019). Effect of liquid platelet-rich fibrin and platelet-rich plasma on the regenerative potential of dental pulp cells cultured under inflammatory conditions: A comparative analysis. J. Endod., 45 (8), 1000-1008. Retrieved from: https://doi.org/10.1016/j.joen.2019.04.002.

17. Jovani-Sancho, M. D., Sheth, C. C., MarquésMateo, M., \& Puche-Torres, M. (2016). Platelet-rich plasma:

A study of the variables that may influence its effect on bone regeneration. Clinical Implant Dentistry and Related Research, 18 (5), 1051-1064. Retrieved from: https://doi. org/10.1111/cid.12361.

18. Huang, Y., Bornstein, M.M., Lambrichts, I., Yu, H.Y., Politis, C., \& Jacobs, R. (2017). Platelet-rich plasma for regeneration of neural feedback pathways around dental implants: a concise review and outlook on future possibilities. Int. J. Oral Sci., 9 (1), 1-9. Retrieved from: https://doi. org/10.1038/ijos.2017.1

\section{ОЦЕНКА ПЕРСПЕКТИВНОСТИ ПРИМЕНЕНИЯ ОСТЕОИНДУКТИВНЫХ МАТЕРИАЛОВ ПО ДАННЫМ ДЕНСИТОМЕТРИИ ДЛЯ РЕКОНСТРУКЦИИ ДЕФЕКТОВ КОСТНОЙ ТКАНИ В ДИНАМИКЕ ЭКСПЕРИМЕНТА В ПОСЛЕОПЕРАЦИОННОМ ПЕРИОДЕ}

๑Ю. Ю. Лысоконь

\section{Тернопольский национальный медицинский університет имени И. Я. Горбачевского МОз Украины}

РЕЗЮМЕ. Костная ткань для большинства специалистов, работающих в области медицины, является неизвестной частью в организме человека. Нарушение минеральной плотности костной ткани (МПКТ), по данным Всемирной организации здравоохранения, занимает четвертое место в мире по распространенности после сердечно-сосудистых, онкологических заболеваний и сахарного диабета.

На данный момент использование обогащенной тромбоцитами плазмы (ОТП) является одним из успешных направлений тканевой инженерии и клеточной терапии в медицине. Использование факторов роста особенно интересно в тех случаях, когда эффективность костных материалов и остеоинтеграции достаточно сомнительна (например, при выраженом остеопорозе или рубцовых изменениях тканей).

Цель - оценить перспективность применения остеоиндуктивих материалов для реконструкции дефектов костной ткани.

Материал и методы. Остеопластические свойства материалов исследовали на модели костного дефекта бедренной кости диафизарной зоны у четырехмесячных крыс породы Вистар. Было сформировано 4 экспериментальные группы: контрольная группа (интактные животные) - 12 особей; I группа - 14 животных, для заживления костного дефекта у которых применяли остеопластический материал «mp3 OsteoBiol»; II группа - 13 животных, заполнение костного дефекта у которых проводили обогащенной тромбоцитами плазмой (ОТП); III группа 15 животных, у которых при аугментации костного дефекта применяли композицию «mp3 OsteoBiol + OTП». Для получения обогащенной тромбоцитами плазмы крови (ОТП) у больного с помощью венопункции забирали 30 мл крови, которую центрифугировали с двойным циклом оборотов, после чего в пробирке кровь делилась на 3 части. Шприцом отбирали среднюю, тягучую массу желтоватого цвета (ОТП). При проведении исследований осуществляли локальную денситометрию с целью измерения оптической плотности костной ткани. Статистическая обработка полученных результатов проведена на персональном компьютере с помощью лицензионных программ «Microsoft Excel» i «Statistica».

Результаты. По результатам исследований через 3 месяца было установлено, что максимальное значение МПКТ у интактных животных статистически не отличалась от аналогичного параметра у крыс III группы $\left((1199,25 \pm 63,70) \mathrm{HU}\right.$ и $(1145,0 \pm 62,71)$ HU соответственно, p, $\left.p_{1}>0,05, p_{2}<0,01\right)$. При этом у животных I и II экспериментальных групп максимальные значения МПКТ были в 1,2 раза $(p<0,05)$ и в 1,4 раза $\left(p_{1}<0,05\right)$ соответственно ниже относительно данных этого параметра у животных контрольной группы. Минимальные данные МПКТ у крыс контрольной и III экспериментальной групп составили между собой $(924,19 \pm 67,00) \mathrm{HU}$ и $(849,26 \pm 59,22) \mathrm{HU}, \mathrm{p}>0,05, \mathrm{P}_{1}$ $\mathrm{P}_{2}<0,05$ соответственно). При этом данные этого параметра у крыс I и II подопытных групп оставались в 1,5 раза меньше, чем у животных контрольной группы, p<0,01, p >0,05. В то же время, анализ средних данных МПКТ показал, что значения этого параметра составили между собой у животных контрольной и III подопытных групп, p>0,05, $P_{1}, P_{2}<0,05$. Среднее значение МПКТ у животных I и II экспериментальных групп было в 1,2 раза и в 1,3 раза, $\mathrm{p}_{1}>0,05$, ниже, чем у животных контрольной группы, $\mathrm{p}<0,05$.

Выводы. По данным клинических признаков послеоперационного периода, и денситометрических исследований установлено, что предложенная нами композиция, которая содержала «mp3 OsteoBiol» и обогащенную тромбоцитами плазму крови, способствовала ускорению процесса регенерации костной ткани, по сравнению с группами, где применялись вышеупомянутые препараты по отдельности, без воспалительного процесса и с формированием вновь образованной кости, которая имела зрелый характер.

КЛЮЧЕВЫЕ СЛОВА: остеопластический материал; денситометрия; послеоперационный период; обогащенная тромбоцитами плазма; факторы роста; регенерация костной ткани. 
Огляди літератури, оригінальні дослідження, погляд на проблему, випадок з практики, короткі повідомлення ASSESSMENT OF PROSPECTIVITY OF APPLICATION OF OSTEOINDUCTIVE MATERIALS ACCORDING TO THE DATA OF DENSITOMETRY FOR RECONSTRUCTION OF BONE TISSUE DEFECTS IN DYNAMICS OF THE EXPERIMENT IN THE POSTOPERATIVE PERIOD

○Yu. Yu. Lysokon

\section{Horbachevsky Ternopil National Medical University}

SUMMARY. Bone tissue is an unknown part of the human body for most medical professionals. Bone mineral density disorder (BMD), according to the World Health Organization, is the fourth most common in the world after cardiovascular disease, cancer and diabetes.

At present, the use of platelet-rich plasma (PRP) is one of the successful areas of tissue engineering and cell therapy in medicine. The use of growth factors is particularly interesting in cases where the effectiveness of bone material and osteointegration is questionable (for example, in severe osteoporosis or scar tissue changes).

The aim of the study - to evaluate the prospects of using osteoinductive materials for the reconstruction of bone defects.

Material and Methods. Osteoplastic properties of the materials were studied in a model of a bone defect of the femur of the diaphyseal zone in Wistar rats, four months old. 4 experimental groups were formed: control group (intact animals) - 12 individuals; Group I - 14 animals, osteoplastic material "mp3 OsteoBiol" was used to heal the bone defect; Group II - 13 animals, filling the bone defect with platelet-rich plasma (PLP); Group III - 15 animals, with bone defect augmentation used the composition "mp3 OsteoBiol + ZTP". To obtain platelet-rich blood plasma (PRP) from the patient, $30 \mathrm{ml}$ of blood was taken by venipuncture, which was centrifuged at double speed, after which the blood in the test tube was divided into 3 parts. The syringe was used to select the average, viscous mass of yellowish color (PRP). During the studies, local densitometry was performed to measure the optical density of bone tissue. Statistical processing of the obtained results was performed on a personal computer using the licensed programs "Microsoft Excel" and "Statistica".

Results and Discussion. According to the results of studies after 3 months, it was found that the maximum value of BMD in intact animals did not differ statistically from the same parameter in rats of group III (1199.25 \pm 63.70$) \mathrm{HU}$ and $(1145.0 \pm 62.71) \mathrm{HU}$, respectively, $\left.\mathrm{p}, \mathrm{p}_{1}>0.05, \mathrm{p}_{2}<0.01\right)$. In this case, in animals of I and II experimental groups, the maximum values of BMD were 1.2 times, $\mathrm{p}<0.05$, and 1.4 times, $\mathrm{p}_{1}<0.05$, respectively, lower relative to the data of this parameter in animals of the control group. The minimum BMD data in rats of the control and III experimental groups were equal to each other $(924.19 \pm 67.00) \mathrm{HU}$ and $(849.26 \pm 59.22) \mathrm{HU}, \mathrm{p}>0.05, \mathrm{p}_{1}, \mathrm{p}_{2}<0.05$, respectively). At the same time, the data of this parameter in rats of I and II experimental groups remained 1.5 times less than the data in animals of the control group, $\mathrm{p}<0.01, \mathrm{p}_{1}>0.05$. At the same time, the analysis of the mean BMD data showed that the values of this parameter were equal to each other in the animals of the control and III experimental groups, $p>0.05, \mathrm{p}_{1}, \mathrm{P}_{2}<0.05$. At the same time, the mean value of BMD in animals of I and II experimental groups was 1.2 times and 1.3 times, $p_{1}>0.05$, lower than in animals of the control group, $\mathrm{p}<0.05$.

Conclusions. According to the clinical signs of the postoperative period and densitometric studies, it was found that our proposed composition containing "mp3 OsteoBiol" and platelet-rich blood plasma, accelerated the process of bone regeneration, compared with the groups where the above-mentioned agents were used alone with the formation of a newly formed bone, which had a mature character.

KEY WORDS: osteoplastic material; densitometry; postoperative period; platelet-rich plasma; growth factors; bone regeneration.

Отримано 12.08.2020 